\title{
Hwanghaeicola aestuarii gen. nov., sp. nov., a moderately halophilic bacterium isolated from a tidal flat of the Yellow Sea
}

Correspondence

Che Ok Jeon

cojeon@cau.ac.kr

\author{
Jeong Myeong Kim, ${ }^{1}$ Ji Young Jung, ${ }^{1}$ Ho Byoung Chae, ${ }^{2}$ Woojun Park ${ }^{3}$ \\ and Che Ok Jeon ${ }^{1}$ \\ 1 Department of Life Science, Chung-Ang University, Seoul 156-756, Republic of Korea \\ ${ }^{2}$ Environmental Biotechnology National Core Research Center, Gyeongsang National University, \\ Jinju 660-701, Republic of Korea \\ ${ }^{3}$ Division of Environmental Science and Ecological Engineering, Korea University, Seoul 136-701, \\ Republic of Korea
}

\begin{abstract}
A moderately halophilic Gram-staining-negative bacterium, designated strain $\mathrm{Y}^{2} 6^{\top}$, was isolated from a tidal flat of Taean coast in South Korea. Cells were strictly aerobic, motile cocci with a single flagellum and showed catalase- and oxidase-positive reactions. Growth of strain $\mathrm{Y}^{2} 6^{\top}$ was observed at $15-35{ }^{\circ} \mathrm{C}$ (optimum $25-30{ }^{\circ} \mathrm{C}$ ), $\mathrm{pH}$ 6.0-8.0 (optimum pH 6.5-7.5) and with 1.5$6.0 \%(\mathrm{w} / \mathrm{v}) \mathrm{NaCl}$ (optimum 2.0-3.0\%). The predominant fatty acids were $\mathrm{C}_{18: 1} \omega 7 \mathrm{c}(66.2 \%)$, $\mathrm{C}_{16: 0}(12.4 \%)$ and $\mathrm{C}_{10: 0} 3-\mathrm{OH}(5.0 \%)$ and the $\mathrm{G}+\mathrm{C}$ content of the genomic DNA was $61.0 \mathrm{~mol} \%$. Strain $\mathrm{Y} 26^{\top}$ contained ubiquinone-10 (Q-10) as the major respiratory quinone. Comparative 16S rRNA gene sequence analysis showed that strain $\mathrm{Y}_{2} 6^{\top}$ formed a distinct phyletic lineage from other genera within the Roseobacter clade of the class Alphaproteobacteria and was most closely related to members of the genera Maribius, Maritimibacter and Palleronia with 93.8-94.6\% sequence similarity. On the basis of chemotaxonomic data and molecular properties, strain $Y^{2} 6^{\top}$ represents a novel genus, Hwanghaeicola, within the family Rhodobacteraceae, for which the name Hwanghaeicola aestuarii gen. nov., sp. nov. is proposed. The type strain is $\mathrm{Y}^{2} 6^{\top}\left(=\right.$ KACC $13705^{\top}=$ DSM $\left.22009^{\top}\right)$.
\end{abstract}

Since a Gram-negative bacterium belonging to the Roseobacter clade within the class Alphaproteobacteria was first reported by Shiba (1991), many new genera of the Roseobacter clade have been isolated from various marine environments such as seawater, tidal flats, marine algae, and hypersaline microbial mats (Choi et al., 2007; Lee et al., 2007; Y.-G. Kim et al., 2008; Vandecandelaere et al., 2009; Wang et al., 2009; Yoon et al., 2009; Zheng et al., 2010). The Roseobacter clade is known as one of the most abundant groups in marine environments and its members show diverse physiological and morphological features. The Yellow Sea coasts of the Korean peninsula consist of vast tidal flats known as getbol, which are marine habitats having valuable biological resources such as micro-organisms and marine animals. Therefore, bacteria were isolated from these tidal flats and characterized in our laboratory (Kim et al., 2010). Here, we describe the taxonomic characterization of a novel genus isolated from a flat of the

The GenBank/EMBL/DDBJ accession number for the 16S rRNA gene sequence of strain $Y^{2} 6^{\top}$ is FJ230842.

Maximum-likelihood and maximum-parsimony trees are available with the online version of this paper.
Yellow Sea belonging to the Roseobacter clade, for which the name Hwanghaeicola aestuarii gen. nov., sp. nov. is proposed.

Strain $\mathrm{Y} 26^{\mathrm{T}}$ was isolated from a tidal flat of the Taean coast of the Yellow Sea, South Korea, using a previously described procedure with some modifications (J. M. Kim et al., 2008). Briefly, a sediment sample was serially diluted with marine broth (MB; Difco), spread on marine agar 2216 (MA; Difco) plates and incubated at $25{ }^{\circ} \mathrm{C}$ for 5 days. Colonies were randomly selected and crude lysates containing genomic DNA from respective colonies were prepared by boiling a small amount of cell material in $100 \mu \mathrm{l} 5 \%$ Chelex 100 solution (Bio-Rad) for $10 \mathrm{~min}$ followed by centrifugation at $15000 \mathrm{~g}$ for $10 \mathrm{~min}$. PCR amplification of $16 \mathrm{~S}$ rRNA genes from the crude lysates was performed using the universal primers F1 (5'AGAGTTTGATCMTGGCTCAG-3') and R13 (5'-TACGGYTACCTTGTTACGACTT-3'), as described previously (Lu et al., 2006). The amplicons were double-digested with HaeIII and HhaI. Restriction fragment length polymorphism (RFLP) patterns were analysed on $2.5 \%$ MetaPhore agarose (BioWhittaker) gels and representative PCR 
products containing distinct RFLP patterns were sequenced. The resulting $16 \mathrm{~S}$ rRNA gene sequences were analysed using the BLAST program (http://www.ncbi.nlm. nih.gov/BLAST/) in GenBank. From the analysis, a novel strain belonging to the Roseobacter clade, designated strain $\mathrm{Y}^{2} 6^{\mathrm{T}}$, was selected for further phenotypic and phylogenetic analysis. The strain was routinely grown aerobically on MA at $30{ }^{\circ} \mathrm{C}$ for 3 days, except where indicated otherwise. The strain was stored at $-80{ }^{\circ} \mathrm{C}$ in $\mathrm{MB}$ supplemented with $10 \%(\mathrm{v} / \mathrm{v})$ glycerol for preservation. The type strains of related taxa, including Maribius pelagius B5- $6^{\mathrm{T}}$, Maribius salinus CL-SP27 $7^{\mathrm{T}}$, Palleronia marisminoris $\mathrm{LMG} 22959^{\mathrm{T}}$ and Maritimibacter alkaliphilus HTCC $2654^{\mathrm{T}}$, were used as reference strains for the biochemical tests or fatty acid analysis.

The 16S rRNA gene sequence (1350 nt) of strain $\mathrm{Y} 26^{\mathrm{T}}$ was compared with available 16S rRNA gene sequences from GenBank using the BLAST program to determine an approximate phylogenetic affiliation. Sequence similarity values between the novel isolate and related taxa were evaluated using the Nucleotide Similarity Search program (http://147.47.212.35:8080/; Chun et al., 2007) and aligned by using the CLUSTAL $\mathrm{W}$ software program (Thompson et al., 1994). Phylogenetic trees were reconstructed by using the neighbour-joining, maximum-likelihood and maximumparsimony algorithms available in the PHYLIP software package, version 3.6 (Felsenstein, 2002). The resulting tree topology reconstructed by using the neighbour-joining method was evaluated using a bootstrap analysis based on 1000 resampled datasets with the PHYLIP package. Comparative analysis of the 16S rRNA gene sequences showed that strain $\mathrm{Y} 26^{\mathrm{T}}$ was most closely related to Maribius pelagius $\quad$ B5- $6^{\mathrm{T}}$, Maritimibacter alkaliphilus HTCC $2654^{\mathrm{T}}$ and Maribius salinus CL-SP2 $7^{\mathrm{T}}$ with similarities of $94.6,94.4$ and $94.3 \%$, respectively. These levels of $16 S$ rRNA gene sequence similarity are sufficient to potentially define a new genus (Rosselló-Mora \& Amann, 2001). Phylogenetic analysis based on $16 \mathrm{~S}$ rRNA gene sequences also indicated that strain $\mathrm{Y} 26^{\mathrm{T}}$ formed a distinct phyletic lineage from other related taxa (Fig. 1). The topologies of phylogenetic trees built using the maximumlikelihood and maximum-parsimony algorithms supported the notion that there was no genus group showing a clear phylogenetic relationship with strain $\mathrm{Y}^{\mathrm{T}}{ }^{\mathrm{T}}$ within the Roseobacter clade (Supplementary Fig. S1, available in IJSEM Online).

Temperature and $\mathrm{pH}$ for growth of strain $\mathrm{Y} 26^{\mathrm{T}}$ were examined by growing the isolate at different temperatures $\left(5-45{ }^{\circ} \mathrm{C}\right.$ at $5{ }^{\circ} \mathrm{C}$ intervals) on MA and at different $\mathrm{pH}$ (5.0-10.5 at $0.5 \mathrm{pH}$ unit intervals) in $\mathrm{MB}$. The $\mathrm{pH}$ was adjusted prior to sterilization by the addition of $\mathrm{HCl}$ or $\mathrm{NaOH}$ and measured again after sterilization. Gram staining was performed using the bioMérieux Gram Stain kit according to the instructions of the manufacturer. Oxidase activity was tested by oxidation of $1 \%(\mathrm{w} / \mathrm{v})$ tetramethyl-p-phenylenediamine (Merck), and catalase activity was evaluated by the production of oxygen bubbles

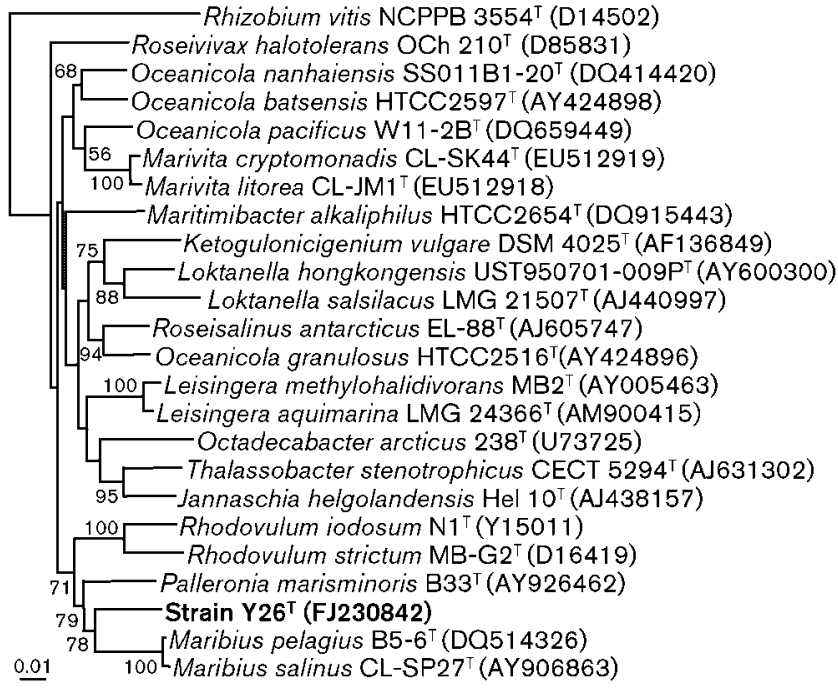

Fig. 1. Neighbour-joining tree based on 16S rRNA gene sequences showing the phylogenetic relationships of strain $Y 26^{\top}$ and related taxa. Bootstrap values are shown as percentages of 1000 replicates, when greater than $50 \%$, at branch points. Rhizobium vitis NCPPB $3554^{\top}$ (D14502) was used as an outgroup. Bar, 0.01 changes per nucleotide position.

in $3 \%(\mathrm{v} / \mathrm{v})$ aqueous hydrogen peroxide solution (Smibert \& Krieg, 1994). Cell morphology, motility and the presence of flagella were studied using phase-contrast microscopy and transmission electron microscopy (JEM-1010, JEOL) with 2-day-old cells grown on MA as described previously (Jeon et al., 2004). Requirement and tolerance of $\mathrm{NaCl}$ were determined using synthetic ZoBell broth $(0.5 \%$ Bacto peptone, $0.1 \%$ yeast extract and $0.01 \%$ ferric citrate) with modified artificial seawater [ASW; $0-15 \%$ $(\mathrm{w} / \mathrm{v}) \mathrm{NaCl}$ at $0.5 \%$ intervals, $5.94 \mathrm{~g} \mathrm{MgSO}_{4} \cdot 7 \mathrm{H}_{2} \mathrm{O}, 4.53 \mathrm{~g}$ $\mathrm{MgCl}_{2} .6 \mathrm{H}_{2} \mathrm{O}, 0.64 \mathrm{~g} \mathrm{KCl}$ and $1.3 \mathrm{~g} \mathrm{CaCl}_{2}$ per litre] (Kahng et al., 2009). Ionic requirements were determined using synthetic ZoBell broth with the following combinations of salts (all w/v): (i) $3.0 \% \mathrm{NaCl}$; (ii) $3.0 \% \mathrm{NaCl}, 0.6 \%$ $\mathrm{MgCl}_{2} \cdot 6 \mathrm{H}_{2} \mathrm{O}$ and $0.3 \% \mathrm{MgSO}_{4} \cdot 7 \mathrm{H}_{2} \mathrm{O}$; (iii) $3.0 \% \mathrm{NaCl}$, $0.6 \% \mathrm{MgCl}_{2} .6 \mathrm{H}_{2} \mathrm{O}, 0.3 \% \mathrm{MgSO}_{4} \cdot 7 \mathrm{H}_{2} \mathrm{O}$ and $0.06 \% \mathrm{KCl}$; and (iv) $3.0 \% \quad \mathrm{NaCl}, \quad 0.6 \% \quad \mathrm{MgCl}_{2} .6 \mathrm{H}_{2} \mathrm{O}, \quad 0.3 \%$ $\mathrm{MgSO}_{4} .7 \mathrm{H}_{2} \mathrm{O}, 0.06 \% \mathrm{KCl}$ and $0.2 \% \mathrm{CaCl}_{2} .2 \mathrm{H}_{2} \mathrm{O}$ (Choi et al., 2007). Nitrate reduction was assessed according to the method of Lányí (1987). Biochemical features were characterized by using the API 20E and API 20NE kits as recommended by the manufacturer (bioMérieux) except that the kits were incubated for 3 days at $30{ }^{\circ} \mathrm{C}$; all suspension media were supplemented with ASW containing $3.0 \%(\mathrm{w} / \mathrm{v}) \mathrm{NaCl}$. Additional enzyme activities were determined by the API ZYM system (bioMérieux) at $30{ }^{\circ} \mathrm{C}$ based on the manufacturer's instructions. Antibiotic susceptibility tests were performed on MA in duplicate using filter-paper discs ( $8 \mathrm{~mm}$ diameter) containing the following antibiotics: ampicillin $(10 \mu \mathrm{g})$, polymyxin $\mathrm{B}$ $(100 \mathrm{U})$, streptomycin $(50 \mu \mathrm{g})$, penicillin $\mathrm{G}(10 \mathrm{IU})$, 


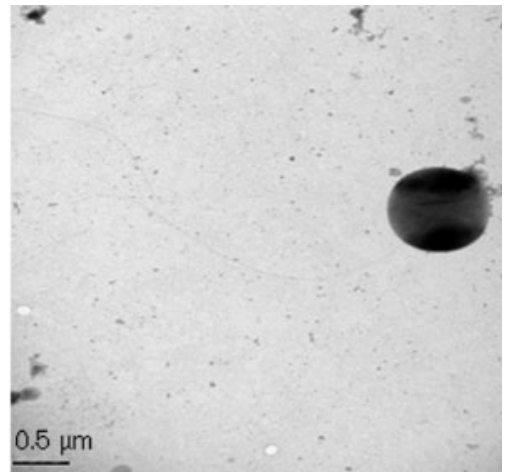

Fig. 2. Transmission electron micrograph showing the general morphology of a negatively stained cell of strain $\mathrm{Y}_{2} 6^{\top}$ after growth for 2 days at $30{ }^{\circ} \mathrm{C}$ on marine agar. Bar, $0.5 \mu \mathrm{m}$.

gentamicin $(30 \mu \mathrm{g})$, chloramphenicol $(100 \mu \mathrm{g})$, tetracycline $(30 \mu \mathrm{g})$, kanamycin $(30 \mu \mathrm{g})$, lincomycin $(15 \mu \mathrm{g})$, oleandomycin $(15 \mu \mathrm{g})$, carbenicillin $(100 \mu \mathrm{g})$ and novobiocin $(50 \mu \mathrm{g})$. Anaerobic growth was assessed on MA under anaerobic (with 4-10\% $\mathrm{CO}_{2}$ ) conditions using the GasPak Plus system (BBL) at $30{ }^{\circ} \mathrm{C}$ for 15 days.

Strain $\mathrm{Y} 26^{\mathrm{T}}$ grew at temperatures between 15 and $35{ }^{\circ} \mathrm{C}$ (optimum $25-30{ }^{\circ} \mathrm{C}$ ), at $\mathrm{pH}$ 6.0-8.0 (optimum 6.5-7.5) and in the presence of $1.5-6.0 \%(\mathrm{w} / \mathrm{v}) \mathrm{NaCl}$ (optimum 2.0-3.0\%). Bacterial cells were Gram-stain negative, strictly aerobic, motile cocci $(0.8-1.2 \mu \mathrm{m}$ in diameter) with a single flagellum at $30{ }^{\circ} \mathrm{C}$ on MA (Fig. 2). The strain was not able to grow in media with $\mathrm{NaCl}$ as a sole salt, but was able to grow in media containing $\mathrm{Na}^{+}$and $\mathrm{Mg}^{+}$ions. Detailed phenotypic features of strain $\mathrm{Y} 26^{\mathrm{T}}$ are presented in the description and compared with those of closely related taxa in Table 1.

Isoprenoid quinones were analysed using an HPLC (model LC-20A, Shimadzu) equipped with a diode array detector (SPD-M20A, Shimadzu) and a reversed-phase column $(250 \times 4.6 \mathrm{~mm}$, Kromasil, Akzo Nobel) as described by Komagata \& Suzuki (1987). For analysis of fatty acid methyl esters, cells of strain $\mathrm{Y}^{2} 6^{\mathrm{T}}$ were harvested after incubation at $30{ }^{\circ} \mathrm{C}$ for 3 days on MA. Analysis of fatty acid methyl esters was performed according to the

Table 1. Phenotypic characteristics that differentiate strain $Y 26^{\top}$ from other related members of the family Rhodobacteraceae

Strains: 1, strain $\mathrm{Y}^{2} 6^{\mathrm{T}}$ (data from this study); 2, Maribius pelagius B5-6 ${ }^{\mathrm{T}}$ (data from Choi et al., 2007); 3, Maribius salinus CL-SP27 ${ }^{\mathrm{T}}$ (Choi et al., 2007); 4, Palleronia marisminoris LMG 22959 ${ }^{\mathrm{T}}$ (Martínez-Checa et al., 2005; Cho \& Giovannoni, 2006); 5, Maritimibacter alkaliphilus HTCC2654 (Lee et al., 2007). All strains are negative for nitrate reduction. +, Positive; -, negative; (+), weakly positive; R, resistant; s, sensitive.

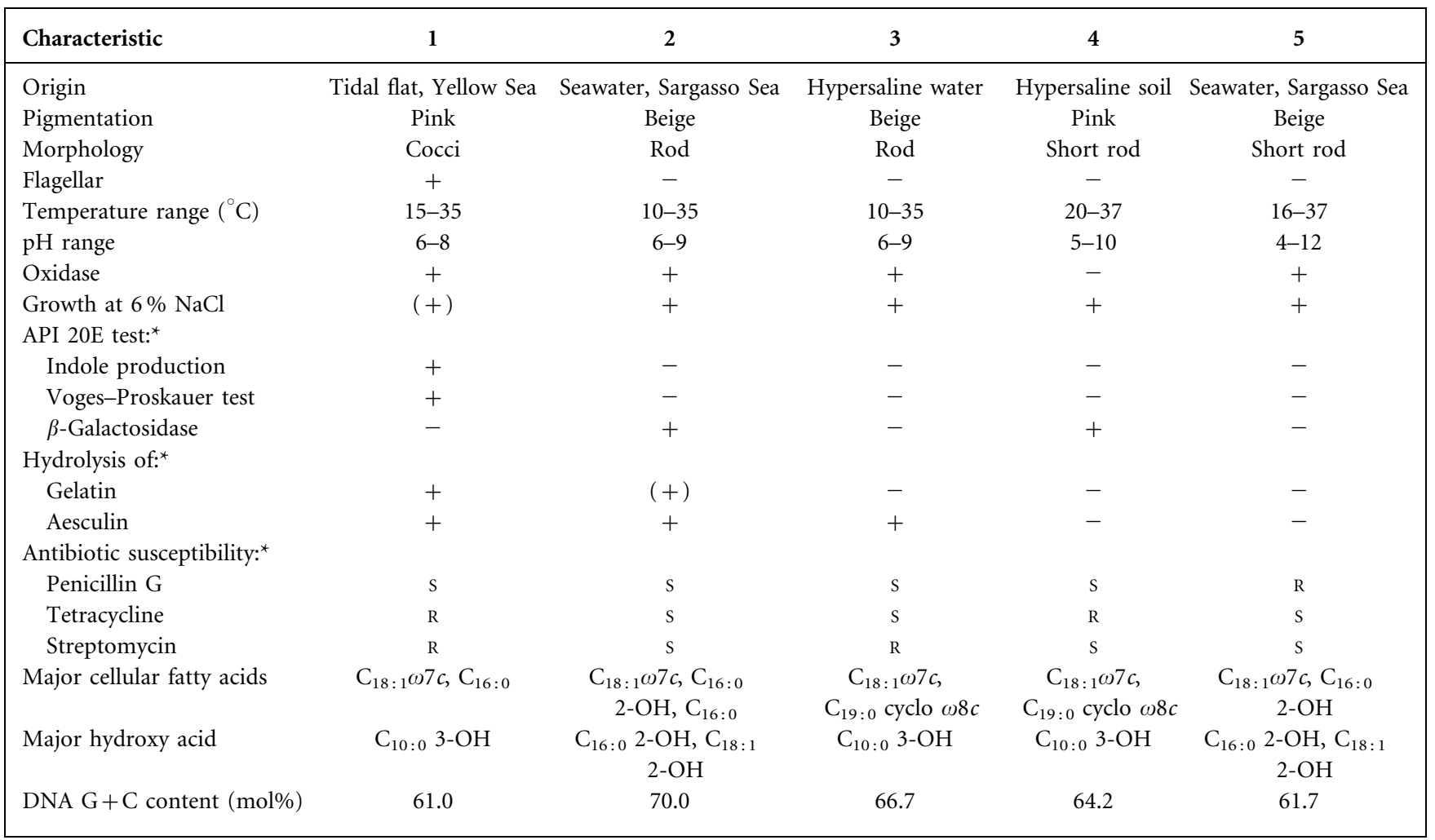

${ }^{\star}$ Data from this study. 
instructions of the Microbial Identification System (MIDI; Microbial ID). The DNA G + C content of strain $Y 26^{T}$ was determined by using an HPLC fitted with a reversed-phase column $(250 \times 4.6 \mathrm{~mm}$, GROM-SIL 100 ODS-2FE, GROM) according to the method of Tamaoka \& Komagata (1984). The major respiratory lipoquinone of strain $\mathrm{Y}_{2}{ }^{\mathrm{T}}$ was ubiquinone Q-10 (Q-10). The major cellular fatty acids $(>2 \%$ of the total fatty acids) were $\mathrm{C}_{18: 1} \omega 7 c(66.2 \%), \mathrm{C}_{16: 0}(12.4 \%), \mathrm{C}_{10: 0} 3-\mathrm{OH}(5.0 \%)$, $\mathrm{C}_{19: 0}$ cyclo $\omega 8 c(3.7 \%)$, unknown 11.799 (3.4\%), 11methyl $\mathrm{C}_{18: 1} \omega 7 c(2.6 \%)$ and $\mathrm{C}_{18: 0}(2.7 \%)$. Although the overall fatty acid profile of strain $\mathrm{Y} 26^{\mathrm{T}}$ was similar to those of phylogenetically related taxa (Table 2), significant

Table 2. Cellular fatty acid compositions (\%) of strain $\mathrm{Y} 26^{\top}$ and related members of the family Rhodobacteraceae

Species: 1, strain $\mathrm{Y}^{2} 6^{\mathrm{T}}$ (this study); 2, Maribius pelagius $\mathrm{B} 5-6^{\mathrm{T}}$ (this study); 3, Maribius salinus CL-SP2 $7^{\mathrm{T}}$ (this study); 4, Palleronia marisminoris LMG $22959^{\mathrm{T}}$ (Martínez-Checa et al., 2005); 5, Maritimibacter alkaliphilus HTCC2654 ${ }^{\mathrm{T}}$ (this study). Data are expressed as percentages of total fatty acids. Fatty acids amounting to less than $0.5 \%$ in all species are not shown. tr, Trace amount $(<0.5 \%)$; - , not detected; ECL, equivalent chain-length.

\begin{tabular}{|c|c|c|c|c|c|}
\hline Fatty acid & 1 & 2 & 3 & 4 & 5 \\
\hline \multicolumn{6}{|l|}{ Straight } \\
\hline $\mathrm{C}_{12: 0}$ & 1.3 & - & 0.7 & - & - \\
\hline $\mathrm{C}_{16: 0}$ & 12.4 & 12.6 & 3.5 & 4.2 & 11.2 \\
\hline $\mathrm{C}_{17: 0}$ & - & $\operatorname{tr}$ & 0.6 & - & 1.0 \\
\hline $\mathrm{C}_{18: 0}$ & 2.7 & 0.6 & 4.7 & 3.4 & 0.6 \\
\hline \multicolumn{6}{|l|}{ Unsaturated } \\
\hline $\mathrm{C}_{17: 1} \omega 8 c$ & 0.5 & - & 0.9 & - & - \\
\hline $\mathrm{C}_{18: 1} \omega 7 c$ & 66.2 & 50.5 & 70.2 & 68.9 & 35.0 \\
\hline 11-methyl $\mathrm{C}_{18: 1} \omega 7 c$ & 2.6 & 9.5 & 3.0 & - & 12.4 \\
\hline $\mathrm{C}_{19: 0}$ cyclo $\omega 8 c$ & 3.7 & $\operatorname{tr}$ & 6.5 & 12.8 & 1.2 \\
\hline $\mathrm{C}_{20: 1} \omega 7 c$ & $\operatorname{tr}$ & - & 1.4 & - & - \\
\hline \multicolumn{6}{|l|}{ Hydroxy } \\
\hline $\mathrm{C}_{10: 0} 3-\mathrm{OH}$ & 5.0 & $\operatorname{tr}$ & 3.7 & 5.0 & 0.6 \\
\hline $\mathrm{C}_{15: 0} 2-\mathrm{OH}$ & - & $\operatorname{tr}$ & - & - & 1.0 \\
\hline $\mathrm{C}_{16: 0} 2-\mathrm{OH}$ & - & 17.5 & - & - & 26.5 \\
\hline $\mathrm{C}_{17: 0} 2-\mathrm{OH}$ & - & $\operatorname{tr}$ & - & - & 0.6 \\
\hline $\mathrm{C}_{16: 1} 2-\mathrm{OH}$ & - & 0.5 & - & - & 0.7 \\
\hline $\mathrm{C}_{18: 1} 2-\mathrm{OH}$ & - & 5.3 & - & - & 7.0 \\
\hline \multicolumn{6}{|l|}{ Summed features ${ }^{*}$} \\
\hline 2 & 1.7 & - & - & - & - \\
\hline 3 & 0.5 & 1.2 & - & - & 1.3 \\
\hline 7 & - & - & 2.0 & - & $\operatorname{tr}$ \\
\hline Unknown ECL 4.870 & - & - & - & 2.3 & - \\
\hline Unknown ECL 11.799 & 3.4 & - & 2.9 & - & - \\
\hline
\end{tabular}

${ }^{\star}$ Summed features represent groups of two or three fatty acids which could not be separated by GLC with the MIDI system. Summed feature 2 contained one or more of $\mathrm{C}_{14: 0} 3-\mathrm{OH}$, iso- $\mathrm{C}_{16: 1} \mathrm{I}$, an unidentified fatty acid with an equivalent chain-length of 10.928 and $\mathrm{C}_{12: 0}$ ALDE. Summed feature 3 contained $\mathrm{C}_{16: 1} \omega 7 c$ and/or iso- $\mathrm{C}_{15: 0}$ 2-OH. Summed feature 7 contained one or more of $\mathrm{C}_{18: 1} \omega 7 c$, $\mathrm{C}_{18: 1} \omega 9 c$ and $\mathrm{C}_{18: 1} \omega 12 t$. differences in the respective proportions of several components clearly distinguished the novel strain from related taxa (Table 2). The DNA G $+\mathrm{C}$ content of strain $\mathrm{Y}^{2} 6^{\mathrm{T}}$ was $61.0 \mathrm{~mol} \%$. Therefore, the physiological, biochemical and phylogenetic properties of strain $\mathrm{Y} 26^{\mathrm{T}}$ support its description as a novel genus within the family Rhodobacteraceae of the class Alphaproteobacteria, for which the name Hwanghaeicola aestuarii gen. nov., sp. nov. is proposed.

\section{Description of Hwanghaeicola gen. nov.}

Hwanghaeicola (Hwang.hae.i'co.la. N.L. n. Hwanghaeum Hwanghae, the Korean name of the Yellow Sea in Korea; L. suff. - cola (from L. n. incola) a dweller, inhabitant; N.L. masc. n. Hwanghaeicola a dweller of the Yellow Sea).

Cells are Gram-negative, strictly aerobic, chemoheterotrophic and moderately halotolerant. Cells are motile cocci with a single flagellum. Oxidase- and catalase-positive. Neither nitrate nor nitrite is reduced. The only isoprenoid quinone detected is ubiquinone-10 (Q-10). The major fatty acids are $\mathrm{C}_{18: 1} \omega 7 c, \mathrm{C}_{16: 0}$ and $\mathrm{C}_{10: 0}$ 3-OH. DNA G+C content is $61.0 \mathrm{~mol} \%$ (HPLC). Phylogenetically, the genus Hwanghaeicola is a member of the family Rhodobacteraceae of the phylum Alphaproteobacteria. The type species is Hwanghaeicola aestuarii.

\section{Description of Hwanghaeicola aestuarii sp. nov.}

Hwanghaeicola aestuarii (aes.tu.a'ri.i L. gen. n. aestuarii of the tidal flat, from where the organism was first isolated).

In addition to the traits reported for the genus description, cells are $0.8-1.2 \mu \mathrm{m}$ in diameter and colonies on MA are pale-pink, convex and round with entire margins. Grows at $15-35{ }^{\circ} \mathrm{C}$ (optimum $25-30{ }^{\circ} \mathrm{C}$ ), $\mathrm{pH}$ 6.0-8.0 (optimum $\mathrm{pH}$ 6.5-7.5) and with $1.5-6.0 \%(\mathrm{w} / \mathrm{v}) \mathrm{NaCl}$ (optimum 2.0-3.0\%). Urea, aesculin and gelatin are hydrolysed. ONPG, indole, tryptophan deaminase and the VogesProskauer test are positive. $\mathrm{H}_{2} \mathrm{~S}$ is not produced and citrate is not utilized (API 20E kit). Negative for assimilation of Larabinose, D-mannose, D-glucose, maltose, D-mannitol, malic acid, potassium gluconate, $\mathrm{N}$-acetylglucosamine, capric acid, adipic acid, trisodium citrate and phenylacetic acid (API 20NE). Alkaline phosphatase, esterase (C4), esterase lipase (C8) and leucine arylamidase activities are present, but trypsin, $\alpha$-galactosidase, $\beta$-galactosidase, $\alpha$ glucosidase, $\beta$-glucosidase, $N$-acetyl- $\beta$-glucosaminidase, $\alpha$ mannosidase and $\alpha$-fucosidase activities are not. Weak enzymic activities are observed for lipase (C14), valine arylamidase, cystine arylamidase, $\alpha$-chymotrypsin, acid phosphatase, naphthol-AS-BI-phosphohydrolase and $\beta$ glucuronidase (API ZYM). Resistant to polymyxin B, streptomycin, gentamicin, kanamycin, ampicillin, oleandomycin, lincomycin, tetracycline and carbenicillin, but sensitive to penicillin $\mathrm{G}$, chloramphenicol and novobiocin. Does not grow in media with $\mathrm{NaCl}$ as a sole salt, but grows in media containing $\mathrm{Na}^{+}$and $\mathrm{Mg}^{2+}$ ions. The major 
cellular fatty acids are $\mathrm{C}_{18: 1} \omega 7 c, \mathrm{C}_{16: 0}$ and $\mathrm{C}_{10: 0} 3-\mathrm{OH}$. The DNA G + C content of the type strain is $61.0 \mathrm{~mol} \%$ (HPLC).

The type strain is $\mathrm{Y}^{2} 6^{\mathrm{T}}\left(=\mathrm{KACC} 13705^{\mathrm{T}}=\mathrm{DSM} 22009^{\mathrm{T}}\right)$, which was isolated from a tidal flat of the Taean coast in South Korea.

\section{Acknowledgements}

These efforts were supported by grants from the BioGreen 21 Program (Code no. 20070301034002), Rural Development Administration and the 21C Frontier Microbial Genomics and Application Center Program, Ministry of Education, Science \& Technology, Korea.

\section{References}

Cho, J. C. \& Giovannoni, S. J. (2006). Pelagibaca bermudensis gen. nov., sp. nov., a novel marine bacterium within the Roseobacter clade in the order Rhodobacterales. Int J Syst Evol Microbiol 56, 855859.

Choi, D. H., Cho, J.-C., Lanoil, B. D., Giovannoni, S. J. \& Cho, B. C. (2007). Maribius salinus gen. nov., sp. nov., isolated from a solar saltern and Maribius pelagius sp. nov., cultured from the Sargasso Sea, belonging to the Roseobacter clade. Int J Syst Evol Microbiol 57, 270275.

Chun, J., Lee, J.-H., Jung, Y., Kim, M., Kim, S., Kim, B. K. \& Lim, Y.-W. (2007). EzTaxon: a web-based tool for the identification of prokaryotes based on $16 \mathrm{~S}$ ribosomal RNA gene sequences. Int J Syst Evol Microbiol 57, 2259-2261.

Felsenstein, J. (2002). PHYLIP (phylogeny inference package) version 3.6a. Distributed by the author. Department of Genome Sciences, University of Washington, Seattle, USA.

Jeon, C. O., Park, W., Ghiorse, W. C. \& Madsen, E. L. (2004). Polaromonas naphthalenivorans sp. nov., a naphthalene-degrading bacterium from naphthalene-contaminated sediment. Int J Syst Evol Microbiol 54, 93-97.

Kahng, H.-Y., Chung, B. S., Lee, D.-H., Jung, J. S., Park, J. H. \& Jeon, C. O. (2009). Cellulophaga tyrosinoxydans sp. nov., a tyrosinaseproducing bacterium isolated from seawater. Int J Syst Evol Microbiol 59, 654-657.

Kim, Y.-G., Hwang, C. Y. \& Cho, B. C. (2008). Pelagicola litoralis gen. nov., sp. nov., isolated from coastal water in Korea. Int J Syst Evol Microbiol 58, 2102-2106.

Kim, J. M., Le, N. T., Chung, B. S., Park, J. H., Bae, J.-W., Madsen, E. L. \& Jeon, C. O. (2008). Influence of soil components on the biodegradation of benzene, toluene, ethylbenzene, and $o-, m$-, and p-xylenes by the newly isolated bacterium Pseudoxanthomonas spadix BD-a59. Appl Environ Microbiol 74, 7313-7320.
Kim, J. M., Lee, S. H., Jung, J. Y. \& Jeon, C. O. (2010). Marinobacterium lutimaris sp. nov., isolated from a tidal-flat of the Yellow Sea. Int J Syst Evol Microbiol 60, 1828-1831.

Komagata, K. \& Suzuki, K. (1987). Lipid and cell-wall analysis in bacterial systematics. Methods Microbiol 19, 161-207.

Lányí, B. (1987). Classical and rapid identification methods for medically important bacteria. Methods Microbiol 19, 1-67.

Lee, K., Choo, Y.-J., Giovannoni, S. J. \& Cho, J.-C. (2007). Maritimibacter alkaliphilus gen. nov., sp. nov., a genome-sequenced marine bacterium of the Roseobacter clade in the order Rhodobacterales. Int J Syst Evol Microbiol 57, 1653-1658.

Lu, S., Park, M., Ro, H.-S., Lee, D. S., Park, W. \& Jeon, C. O. (2006). Analysis of microbial communities using culture-dependent and culture-independent approaches in an anaerobic/aerobic SBR reactor. J Microbiol 44, 155-161.

Martínez-Checa, F., Quesada, E., Martínez-Cánovas, M. J., Llamas, I. \& Béjar, V. (2005). Palleronia marisminoris gen. nov., sp. nov., a moderately halophilic, exopolysaccharide-producing bacterium belonging to the 'Alphaproteobacteria', isolated from a saline soil. Int J Syst Evol Microbiol 55, 2525-2530.

Rosselló-Mora, R. \& Amann, R. (2001). The species concept for prokaryotes. FEMS Microbiol Rev 25, 39-67.

Shiba, T. (1991). Roseobacter litoralis gen. nov., sp. nov., and Roseobacter denitrificans sp. nov., aerobic pink-pigmented bacteria which contain bacteriochlorophyll a. Syst Appl Microbiol 14, 140-145.

Smibert, R. M. \& Krieg, N. R. (1994). Phenotypic characterization. In Methods for General and Molecular Bacteriology, pp. 607-654. Edited by P. Gerhardt, R. G. E. Murray, W. A. Wood \& N. R. Krieg. Washington, DC: American Society for Microbiology.

Tamaoka, J. \& Komagata, K. (1984). Determination of DNA base composition by reversed-phase high-performance liquid chromatography. FEMS Microbiol Lett 25, 125-128.

Thompson, J. D., Higgins, D. G. \& Gibson, T. J. (1994). ClUSTAL W: improving the sensitivity of progressive multiple sequence alignment through sequence weighting, position-specific gap penalties and weight matrix choice. Nucleic Acids Res 22, 4673-4680.

Vandecandelaere, I., Nercessian, O., Segaert, E., Achouak, W., Mollica, A., Faimali, M. \& Vandamme, P. (2009). Nautella italica gen. nov., sp. nov., isolated from a marine electroactive biofilm. Int J Syst Evol Microbiol 59, 811-817.

Wang, Y.-X., Wang, Z.-G., Liu, J.-H., Chen, Y.-G., Zhang, X.-X., Wen, M.-L., Xu, L.-H., Peng, Q. \& Cui, X.-L. (2009). Sediminimonas qiaohouensis gen. nov., sp. nov., a member of the Roseobacter clade in the order Rhodobacterales. Int J Syst Evol Microbiol 59, 1561-1567.

Yoon, J.-H., Kang, S.-J., Lee, J.-S. \& Oh, T.-K. (2009). Lutimaribacter saemankumensis gen. nov., sp. nov., isolated from a tidal flat of the Yellow Sea. Int J Syst Evol Microbiol 59, 48-52.

Zheng, Q., Chen, C., Yan, X.-J., Wang, Y.-N., Zeng, Y.-H., Hao, L.-K., He, W.-H. \& Jiao, N.-Z. (2010). Mameliella alba gen. nov., sp. nov., a marine bacterium of the Roseobacter clade in the order Rhodobacterales. Int J Syst Evol Microbiol 60, 953-957. 